\title{
Filozofia arabska, islamska czy muzułmańska? Kilka uwag terminologicznych ${ }^{1}$
}

\begin{abstract}
There is no agreement among the students of the works of Al-Fārābī, Avicenna and Averroes on how their philosophy should be named. The following terms are most frequently used: Muslim philosophy, Arab philosophy, and Islamic philosophy. A closer look at the arguments of the supporters of each of these choices shows that the reason for those terminological discrepancies depends on the postulated relation between religion and philosophy, or more broadly, between religion and science. We emphasize either the ethnic aspect (Arab) or the dominant culture-forming factor (Islam) depending on the terminology chosen. This article aims to present and analyze the arguments of the supporters of each of the terms. The author focuses on philosophers living in the Middle Ages. The question of which of the aforementioned terms best represents the phenomenon in focus will be seen when we study those terms by putting them together in two pairs: the first, Arab philosophy - Muslim philosophy, and the second, Muslim philosophy - Islamic philosophy.
\end{abstract}

Keywords: Muslim philosophy, Islam, religion, science

${ }^{1}$ Podstawą niniejszego artykułu są rozważania, które zawarłem we wstępie mojej rozprawy doktorskiej pt. Istota i istnienie w filozofii muzułmańskiej. Koncepcje Awicenny oraz Awerroesa i ich recepcja w myśli Tomasza z Akwinu, obronionej w Instytucie Filozofii Uniwersytetu im. Adama Mickiewicza w Poznaniu, maszynopis w posiadaniu autora. Tekst ten jest poszerzoną wersją dociekań zawartych w mojej dysertacji. 


\section{Wstęp}

stotnym elementem filozofii tworzonej w okresie średniowiecza były dociekania prowadzone przez muzułmanów. Ich wkład polegał nie tylko na zachowaniu i późniejszym przekazaniu łacinnikom tekstów Arystotelesa i innych greckich uczonych, ale też na tworzeniu oryginalnych koncepcji i systemów filozoficznych. Pomimo doniosłej roli, jaką odegrali muzułmanie w historii filozofii, wśród badaczy ciągle nie ma zgody, jak określać myśl tworzoną przez takich uczonych, jak Al-Fārābī, Awicenna czy Awerroes. Najczęściej spotykane są trzy sposoby nazywania interesującego mnie w tym artykule zjawiska intelektualnego: filozofia muzułmańska², filozofia arabska ${ }^{3}$ oraz filozofia islamska ${ }^{4}$. Chociaż na pierwszy rzut oka może wydawać się, że powyższe zagadnienie ma charakter czysto językowy, to analiza argumentów zwolenników każdego z tych określeń pokazuje, że u podłoża tego sporu terminologicznego stoi między innymi pytanie o wzajemną relację między religią a filozofią, a jeszcze szerzej mówiąc - między religią a nauką. Jedną z głównych osi tej debaty jest pytanie, na ile uprawnione jest włączanie do rozważań filozoficznych elementów religijnych i na ile myśl silnie zakorzenioną w doktrynie religijnej można określać mianem filozofii. Mamy więc tutaj do czynienia z kolejną odsłoną próby określenia, czym filozofia jest lub czym być powinna. Inny ważny aspekt podejmowany w tych sporach stanowi również pytanie o tożsamość kulturową osób tworzących tę filozofię. Jest tak, gdyż w zależności od wybranej terminologii albo podkreślamy aspekt etniczny (arabskość twórców), albo dominujący czynnik kulturotwórczy (czyli islam) w rejonie i w czasie, w którym żyli przedstawiciele tytułowego nurtu intelektualnego.

Celem niniejszego artykułu będzie przedstawienie i analiza argumentów zwolenników każdego z przytoczonych wyżej określeń i udzielenie odpowiedzi, który z nich w sposób najbardziej adekwatny oddaje to, czym była filozofia tworzona w świecie islamu. Głównie skupię się na myślicielach działających w okresie średniowiecza, ale w niektórych przypadkach odwoływać się będę również do uczonych żyjących i tworzących w okresach późniejszych. To, który z wyżej wy-

${ }^{2}$ K. Pachniak, Filozofia polityki muzułmańskiej na podstawie dzieł AbūHamida al-Ḡazālego, Wydawnictwo Akademickie Dialog, Warszawa 2001.

${ }^{3}$ A. Mrozek, Średniowieczna filozofia arabska, PWN, Warszawa 1967; Awicenna i średniowieczna filozofia arabska, red. A. Aduszkiewicz, M. Gogacz, ATK, Warszawa 1982; Historia filozofii arabskiej, red. P. Adamson, R.C. Taylor, tłum. K. Pachniak, A. Wąs SVD, WAM, Kraków 2015.

${ }^{4}$ O. Leaman, Krótkie wprowadzenie do filozofii islamu, tłum. M. Lipszyc, Fundacja Aletheia, Warszawa 2004; T. Stefaniuk, Al-Kindī i poczq̨tki filozofii w świecie islamu, Wydawnictwo Uniwersytetu Marii Curie-Skłodowskiej, Lublin 2013. Również oryginalny tytuł monografii Henry’ego Corbina brzmi Histoire de la philosophie islamique, a został na język polski przetłumaczony jako Historia filozofii muzułmańskiej. Zob. H. Corbin, Historia filozofii muzułmańskiej, tłum. K. Pachniak, Wydawnictwo Akademickie Dialog, Warszawa 2005. 
mienionych terminów najlepiej oddaje charakter opisywanego zjawiska, uwidoczni się, gdy rozpatrzymy owe określenia, zestawiając je ze sobą w dwie pary - pierwsza to: filozofia arabska a filozofia muzułmańska lub islamska, druga natomiast: filozofia muzułmańska a filozofia islamska. Kluczowa przy odpowiedzi na postawione $\mathrm{w}$ tytule pytanie jest pierwsza $\mathrm{z}$ wymienionych dystynkcji.

\section{Filozofia arabska a filozofia muzułmańska (islamska)}

W polskim piśmiennictwie filozoficznym powszechniejsze jest posługiwanie się terminem „filozofia arabska”. Zwolenniczką tego określenia jest między innymi Anna Mrozek, która w swojej monografii pt. Średniowieczna filozofia arabska stwierdza, że używanie przymiotnika „muzułmańska” dla opisu tego zjawiska intelektualnego jest nieprawidłowe. Argumentuje ona, że dokonuje się wtedy nieuprawnionego pomieszania dwóch płaszczyzn: filozoficznej i religijnej. Jej zdaniem rozważania filozoficzne opierają się na przesłankach rozumowych i powinny być wolne od naleciałości teologicznych. Stanowisko prezentowane przez Mrozek ma niewątpliwie jedną poważną wadę. Gdyby konsekwentnie zaaplikować je do opisu całości historii filozofii, to należałoby również zanegować zasadność takich nazw, jak filozofia chrześcijańska. Natomiast jest to pojęcie powszechnie używane do opisania pewnych zjawisk intelektualnych, które wykształciły się w wyniku interakcji między filozoficznym dorobkiem myślicieli antycznych a chrześcijańskimi koncepcjami teologicznymi ${ }^{5}$. Do podobnego przenikania spuścizny greckiej doszło również na gruncie pozostałych wielkich religii abrahamowych, dotyczyło to także islamu ${ }^{6}$.

Redaktorzy monografii pt. Historia filozofii arabskiej, Peter Adamson i Richard C. Taylor, jak już sugeruje sam tytuł ich książki, uważają, że bardziej adekwatne jest użycie określenia „arabska” niż „muzułmańska”. Jednak inaczej niż polska badaczka, nie negują oni wpływu islamu na kształtowanie się tego nurtu intelektualnego. Punktem wyjścia ich argumentacji jest to, że filozofia w świecie islamu rozpoczęła się od ruchu tłumaczeniowego, w ramach którego teksty greckie były przekładane na arabski. To właśnie język arabski stał się medium, w którym filozofia ta była tworzona i rozpowszechniana na terenach znajdujących się w orbicie kultury arabsko-muzułmańskiej. Badacze ci wskazują także na fakt, że wielu uczonych zaliczanych do omawianego nurtu filozoficznego nie było muzułmanami, ale chrześcijanami czy żydami (dotyczy to zwłaszcza przedstawicieli ruchu tłumaczeniowego). Drugim argumentem, który przytaczają dla uzasadnienia

${ }^{5}$ Współczesnymi przykładami filozofii chrześcijańskiej są neotomizm, personalizm, który nawiązuje od egzystencjalizmu, czy koncepcje łączące myśl chrześcijańską z filozofią dialogu (np. myśl Józefa Tischnera).

${ }^{6}$ K. Pachniak, Nauka i kultura muzułmańska i jej wpływ na średniowiecznq Europę, Collegium Civitas, Wydawnictwo Trio, Warszawa 2010; D. Kokoć, Wpływ spuścizny filozofii greckiej na kulturę islamu, „Przegląd Religioznawczy” 2010, nr 4, ss. 131-140. 
swojego stanowiska, jest to, że ich zdaniem główni przedstawiciele działający w czasie formowania się tej filozofii koncentrowali się bardziej na przyswojeniu i rozwijaniu tekstów antycznych niż na tworzeniu filozofii o stricte religijnym (czyli muzułmańskim) charakterze ${ }^{7}$. Gdy jednak przyjrzymy się tekstom muzułmańskich filozofów z tego okresu, to zauważymy, że czynnik religijny odgrywał w nich ważną rolę. Wątki o charakterze religijnym obecne są u niemal wszystkich filozofów średniowiecznych. Przenikanie się aspektu czysto filozoficznego i religijnego widać u Al-Fārābiego. Pojęcia „Bóg” ten muzułmański uczony używa, gdy analizuje on zagadnienia polityczne (dotyczące koncepcji państwa doskonałego). Natomiast gdy podejmuje zagadnienia metafizyczne i fizyczne, to na określenie bytu najwyższego Al- Fārābī posługuje się filozoficznym pojęciem „Byt Pierwszy”. Także u Awicenny obecne są elementy religijne. W ostatnich częściach swojego głównego dzieła Księga uzdrowienia podejmuje zagadnienia związane z naturą proroctwa czy życia pozagrobowego. Dodatkowo jest on autorem trzech traktatów mistycznych czy eksperymentu myślowego ${ }^{9}$, który miał dowodzić istnienia nieśmiertelnej duszy ${ }^{10}$. Z kolei głównym zagadnieniem, które podejmował Awerroes, było pytanie o naturę relacji między religią a filozofią. W takich tekstach, jak Traktat rozstrzygający czy Rozproszenie rozproszenia przedstawił swoją koncepcję ontologiczną i epistemologiczną, w której zakreślił program autonomii filozofii względem religii, ale, co istotne, swoją argumentację w znacznej mierze oparł na fragmentach Koranu ${ }^{11}$. Nie można zapomnieć również o całej rzeszy mistyków,

${ }^{7}$ Historia filozofii arabskiej, red. P. Adamson, R.C. Taylor, s. 19.

${ }^{8}$ Al-Farabi, Państwo doskonałe. Polityka, tłum. J. Bielawski, PWN, Warszawa 1967. Zob. także: D. Kokoć, Inspiracje helleńskie w filozofii Al-Farabiego, w: Zachód a świat islamu - Zrozumieć Innego, red. I. Kończak, M. Woźniak, Katedra Bliskiego Wschodu i Północnej Afryki UŁ, Łódź 2012, http://kbwipa.uni.lodz.pl/download/zachod_a_swiat_islamu.pdf [dostęp: 21.04.2012], ss. 115-123; idem, Rola intelektu czynnego w poznaniu Boga w metafizyce Al-Fārābiego, „Humaniora. Czasopismo Internetowe” 2013, nr 1, http://humaniora.amu.edu.pl/sites/default/files/ humaniora/6\%20Rola.pdf [dostęp: 22.12.2013], ss. 57-65.

${ }^{9}$ Eksperyment o „latającym człowieku”. Zob. R. Wisnovsky, Awicenna i jego tradycja, w: Historia filozofii arabskiej, red. P. Adamson, R.C. Taylor, ss. 101-109.

${ }^{10}$ Avicenna, The Metaphysics of The Healing, thum. M.E. Marmura, Brigham Young University Press, Pravo, Utah 2005; Avicenna, On Theology, tłum. A.J. Aeberry, Kitab al-Islamiyyah, Dubaj (brak daty wydania).

${ }^{11}$ Averroes (Ibn Rushd), Tahafut al-Tahafut (The Incoherence of the Incoherence), thum. S. van Den Bergh, http://www.newbanner.com/Philosophy/IbnRushd/Tahafut_al-Tahafut_en.pdf [dostęp: 3.11.2014]; Averroës, Decisive Treaties, Epistle Dedicatory, tłum. Ch.E. Butterworth, Brigham Young University Press, Pravo, Utah 2008; Z. Kuksewicz, Awerroizm łaciński trzynastego wieku. Nonkonformistyczny obraz świata i człowieka w średniowieczu, PWN, Warszawa 1971; K. Pachniak, Fasl al-makal Ibn Ruszda, „Studia Antyczne i Mediewistyczne” 2009, nr 7, ss. 33-36; D. Kokoć, Relacja między religiq a filozofiq w Traktacie rozstrzygającym Awerroesa, w: Nie tylko Śródziemnomorze. Problemy polityczne i społeczne świata islamu, red. M. Woźniak, Katedra Bliskiego Wschodu i Północnej Afryki Uniwersytetu Łódzkiego, Łódź 2012, http://kbwipa.uni.lodz.pl/download/nie_tylko_srodziemnomorze.pdf [dostęp: 30.12.2012], ss. 9-18; D. Kokoć, Awerroistyczna doktryna podwójnej prawdy jako próba rozdzielania sfer sa- 
którzy na podstawie swoich doświadczeń mistycznych opracowali systemy filozoficzne, np. Al-Ḡazālī czy Ibn 'Arabīî'.

Już ten pobieżny przegląd poglądów najważniejszych myślicieli muzułmańskich okresu średniowiecza pozwala wykazać, że religia odegrała ważną rolę w kształtowaniu się ich poglądów i była obecna jako punkt odniesienia dla ich sposobu ujmowania rzeczywistości ${ }^{13}$. Na silny związek pomiędzy filozofią tworzoną w świecie islamu w okresie średniowiecza a ideami religijnymi wypływającymi z Koranu i sunny wskazuje Henry Corbin. W Historii filozofii muzułmańskiej stwierdza, że właśnie mówienie o „filozofii arabskiej” jest niewłaściwe, gdyż pomija się w ten sposób istotny wpływ na rozwój tej filozofii religii, którą wyznawali tworzący ją myśliciele. Jak pisze we wspomnianej pracy:

Zamiast przesądzać o opiniach bądź „ortodoksji” kwestionującej nasze określenie „muzułmański” w stosunku do tego czy innego filozofa, będziemy mówić o „filozofii muzułmańskiej” jako o filozofii, której rozkwit i odmiany są związane przede wszystkim

crum i profanum na gruncie filozofii przyrody, „Przegląd Religioznawczy” 2012, nr 4, ss. 3-12; D. Kokoć, Awerroistyczna doktryna podwójnej prawdy a współczesne dyskusje na temat relacji między naukq a wiarq, „Humaniora. Czasopismo Internetowe” 2015, nr 3, http://humaniora. amu.edu.pl/sites/default/files/humaniora/Humaniora\%2011/Kokoc_Hum_3_15_s.pdf [dostęp: 1.07.2016], ss. 73-83.

12 Ibn 'Arabī, Księga o podróży nocnej do najbardziej szlachetnego miejsca, tłum. J. Wronecka, PWN, Warszawa 1990; Ibn 'Arabī, Traktat o miłości, tłum. J. Wronecka, Wydawnictwo Naukowe PWN, Warszawa 1995; Ibn 'Arabi, Drogi do Pana Mocy, tłum. J. Szczepański, Dom Wydawniczy Rebis, Poznań 2003; Ibn al’Arabi, The Bezels of Wisdom, tłum. R.W.J. Austin, Paulist Press, New Jersey 1980; A.H. Al-Ḡazālī, Nisza świateł, tłum. J. Wronecka, PWN, Warszawa 1990; A.H. Al-Ghazali, Sprawiedliwa waga. Ratunek przed zabłądzeniem, tłum. K. Pachniak, Wydawnictwa Uniwersytetu Warszawskiego, Warszawa 2008; D. Kokoć, Elementy racjonalności w mistyce muzułmańskiej, „Racjonalia. Z punktu widzenia humanistyki” 2011, nr 1, ss. 55-68; idem, Mistyczna teoria miłości według Ibn “Arabiego”, „Przegląd Religioznawczy” 2011, nr 4, ss. 73-82; idem, Od kalāmu do sufizmu - intelektualno-religijna droga Al-Ḡazālego w Ratunku przed zabłądzeniem, w: Sfery refleksji religioznawczej, red. R. Ilnicki, J. Iwanicki, Wydawnictwo Naukowe WNS UAM, Poznań 2012, ss. 115-123; idem, Werset światła w mistyczne interpretacji Al-Ghazalego”, „Internetowy Magazyn Filozoficzny Hybris” 2013, nr 20, http://magazynhybris. com/images/teksty/20/Hybris_20.\%282013\%29.PDF [dostęp: 3.04.2013], ss. 120-135; idem, Esencjalny charakter metafizyki Ibn 'Arabiego, w: Ratio, religio, humanitas. Miscellanea dedykowane Profesorowi Zbigniewowi Drozdowiczowi, red. E. Jeliński, Z. Stachowski, S. Sztajer, Wydawnictwo Naukowe WNS UAM, Poznań 2015, ss. 155-163.

${ }^{13}$ Podczas jednej z dyskusji dotyczącej tytułowego tematu spotkałem się z argumentacją, że nie można mówić o „filozofii muzułmańskiej”, gdyż filozofowie ci często byli ofiarami oskarżeń o herezję, a ich koncepcje nie zyskały uznania ze strony muzułmańskiej ortodoksji. Faktem jest, że Al-Ḡazālī występował ostro przeciw koncepcjom metafizycznym Al-Fārābiego i Awicenny, uznając je za bezbożne, a Awerroes został wygnany za nieprawomyślność. Podobnie jak Terturliana czy Orygenesa, pomimo ich potępienia, zalicza się do grona myślicieli chrześcijańskich, tak samo to, że wspomniani wyżej uczeni spotkali się z krytyką ortodoksyjnych teologów. Nie przekreśla to zasadności mówienia o ich myśli jako o „filozofii muzułmańskiej”. Dodatkowo nie można zapomnieć o elemencie autoidentyfikacji, a w większości przypadków filozofowie ci identyfikowali się jako muzułmanie. 
ze zjawiskiem duchowym i religijnym islamu, i która świadczy o tym, że nie jest prawdą, iż islam znalazł swój odpowiedni i decydujący wyraz jedynie w prawie, jurysprudencji zwanej fikh, jak często niesłusznie się utrzymuje ${ }^{14}$.

Tomasz Stefaniuk przytacza z kolei dwanaście kwestii podejmowanych przez filozofów muzułmańskich, a które miały mieć swoje źródło w muzułmańskiej teologii. Zdaniem polskiego badacza, to właśnie tylko uwzględniając inspirującą rolę religijnych koncepcji wynikających z islamu, można wytłumaczyć zainteresowanie muzułmańskich uczonych tymi problemami. Wymienione przez Stefaniuka zagadnienia to między innymi problem filozoficznych konsekwencji przyjęcia ścisłego monoteizmu (w tym problem relacji atrybutów Boga w kontekście jego niepodzielności i jedyności), pytanie o naturę objawienia (na przykład czy Koran jest odwieczny, czy też został stworzony), rozważania dotyczące stworzenia świata, ale też kwestie etyczne, polityczne czy antropologiczne, które były formułowane w ramach wyznaczonych przez islam ${ }^{15}$.

Znacznie mocniejszym argumentem uzasadniającym poprawność określenia „filozofia arabska” jest przesłanka językowa. W okresie średniowiecza język arabski był lingua franca świata islamu. To w tym języku tworzono zarówno zdecydowaną większość dzieł naukowych, w tym filozoficznych, jak również literaturę piękną. Nawet myśliciele, którzy nie byli pochodzenia arabskiego, posługiwali się językiem arabskim. Przykładem może być Al-Fārābī, który był pochodzenia tureckiego, ale wychowany został w kulturze arabskiej i właśnie w tym języku pisał swoje traktaty $^{16}$. Również Marek M. Dziekan wskazuje, że elementem, który pozwala zaliczyć jakiś lud do kultury arabskiej, jest wspólnota językowa ${ }^{17}$. „Argument językowy” pomimo swojej dużej mocy, jednak nie jest rozstrzygający, a Corbin uważa, że nie ma on w ogóle uzasadnienia. Ten francuski uczony wskazuje, że taka „językowa definicja” rodzi dużo trudności i nie jest adekwatna. Chociaż, jak już zostało wspomniane, znaczna część dorobku kultury muzułmańskiej została spisana w języku arabskim, to nie był on jedynym, w którym tworzono. Po okresie dominacji arabskiej w świecie islamu do głosu zaczęły dochodzić żywioły perski czy turecki. Wielu myślicieli, zwłaszcza ismā’̄ilickich, tworzyło w języku perskim, również Awicenna jedno ze swoich głównych dzieł, Księgę wiedzy, napisał właśnie w tym języku.

Argument odwołujący się do języka, w którym tworzyli przedstawiciele danej filozofii, traci ponadto na swojej sile, gdy zastosujemy go do filozofii europejskiej. Oczywiście w okresie średniowiecza sytuacja w Europie była podobna jak w świecie islamu, to znaczy językiem dominującym była na Zachodzie łacina, a na

14 H. Corbin, Historia filozofii muzułmańskiej, s. 8.

15 T. Stefaniuk, Al-Kindī i poczq̨tki filozofii..., ss. 30-31.

16 J. Bielawski, Al-Farabi - drugi nauczyciel. Życie i dzieło, w: Al-Farabi, Państwo doskonałe..., D. Kokoć, Inspiracje helleńskie...

17 M.M. Dziekan, Dzieje kultury arabskiej, Wydawnictwo Naukowe PWN, Warszawa 2008. 
Wschodzie greka. Jednak zmieniło się to w okresie nowożytnym, wraz z rozwojem języków narodowych. Mimo że łacina zaczęła tracić na znaczeniu, to jednak przez bardzo długi czas była językiem nauki. Tacy filozofowie, jak Kartezjusz czy Gottfried Wilhelm Leibniz część swoich traktatów napisali w języku łacińskim, mimo to nie są oni klasyfikowani jako myśliciele łacińscy, ale jako przedstawiciele odpowiednio filozofii francuskiej i niemieckiej.

Kolejną przesłanką za tym, że przymiotnik „muzułmańska” jest bardziej adekwatny, jest trudność wynikająca z samej definicji kultury arabskiej. Marek M. Dziekan wskazuje, że tym, co łączy zróżnicowane społeczności arabskie, jest jedność kulturowa i językowa. Nie można jednak utożsamiać tej kultury z kulturą arabsko-muzułmańską, gdyż zakresy tych dwóch pojęć są różne. W przypadku tej drugiej istotnym elementem, który ją konstytuuje i stanowi jej źródło, jest religia. Gdy rozpatrujemy kulturę arabską, to musimy uwzględnić między innymi okres przedislamski, tzw. okres Ğāhiilyyi ${ }^{18}$. Natomiast nie stanowi on części kultury arabsko-muzułmańskiej, podobnie jak nie zaliczają się do niej wytwory arabskich chrześcijan czy Żydów ${ }^{19}$.

Podkreślić też należy, że wielu z myślicieli muzułmańskich nie było z pochodzenia Arabami. Wspomniany Al-Fārābī był pochodzenia tureckiego, Awicenna był najprawdopodobniej Persem. Również wielu intelektualistów, których Corbin zalicza do szeroko rozumianej filozofii muzułmańskiej, jak Al-Ḡazālī, czy myśliciele z nurtu iluminacjonizmu, jak As-Suhrawardī, czy przedstawiciele szkoły w Isfahanie - Mīr Dāmād i Mullā Șadrā, jak również wielu mistyków (na przykład Rumi), byli także Persami. Dlatego też mówienie o „filozofii arabskiej” nie wytrzymuje próby, gdy zastosujemy kryterium etniczne.

${ }^{18} \check{G} a \overline{h i l i y y a}$, „okres niewiedzy” - tak muzułmanie nazywają czas poprzedzający misję proroczą Muḥammada i objawienie Koranu. Trwał on od około 500 r. n.e. do momentu, w którym prorok islamu rozpoczął swoją działalność. Nazwa ta wywodzi się stąd, że w tym czasie według muzułmanów, Arabowie byli pozbawieni prawdziwej wiedzy o Bogu, przez co oddawali się bałwochwalstwu, co przejawiało się między innymi politeizmem. Zob. J. Bielawski, Islam, Krajowa Agencja Wydawnicza, Warszawa 1980; idem, Wprowadzenie, w: Koran, tłum. J. Bielawski, PIW, Warszawa 2004; J. Danecki, Podstawowe wiadomości o islamie, t. I, Wydawnictwo Akademickie Dialog, Warszawa 2002; idem, Kultura islamu. Słownik, Wydawnictwa Szkolne i Pedagogiczne, Warszawa 1997; M.M. Dziekan, Dzieje kultury...; idem, Symbolika arabsko-muzułmańska. Mały słownik, Wydawnictwo Księży Werbistów Verbinum, Warszawa 1997; E. Machut-Mendecka, Archetypy islamu, Wydawnictwo Psychologii i kultury Eneteia, Warszawa 2006; E. Szymański, Islam pierwotny, w: Zarys dziejów religii, red. J. Keller, Państwowe Wydawnictwo „Iskry”, Warszawa 1988, ss. 750-768; M. Eliade, Historia wierzeń i idei religijnych, t. III, tłum. A. Kuryś, Instytut Wydawniczy Pax, Warszawa 2008.

${ }^{19}$ M.M. Dziekan, Dzieje kultury... 


\section{Filozofia muzułmańska a islamska}

Powyższe argumenty ukazują, że element religijny odgrywał istotną rolę, zarówno w interesującym mnie nurcie intelektualnym, jak również w samej kulturze, w której owo zjawisko powstało i się rozwijało. Przesłanki powyższe pozwalają przyjąć, że określenie „filozofia arabska” nie jest adekwatne i nie oddaje w pełni istoty przedmiotu, który ma opisywać. Większą trudnością jest natomiast rozstrzygnięcie, czy lepiej jest mówić o „filozofii muzułmańskiej” czy też „islamskiej”. Trudność wynika między innymi stąd, że często przymiotniki „muzułmański” i „islamski” używane są jako synonimy. Jednak jak zauważa imam Abduljalil Sajid, traktowanie tych dwóch określeń jak wyrazy równoznaczne jest błędem. Jak pisze:

Większość ludzi sądzi, że są to synonimy, których można używać zamiennie i często mówią „islamski” wtedy, gdy powinni powiedzieć „muzułmański” i na odwrót ${ }^{20}$.

Zdaniem tego muzułmańskiego duchownego słowo „islam” odnosi się tylko i wyłącznie do swoistej postawy życiowej i sposobu postępowania, które oparte są na przekazie zawartym w Koranie oraz w sunnie. Natomiast muzułmaninem jest ten, kto świadomie i kierując się swoją wolną wolą decyduje się podążać w swoim życiu za zasadami, które wynikają z islamu²1.

Janusz Danecki wskazuje również na pewien element tradycji językowej w polskim piśmiennictwie naukowym. We wstępie do swojej monografii Podstawowe wiadomości o islamie stwierdza, że przymiotnik „muzułmański” jest już zakorzeniony w języku polskim, dlatego też stwierdza on, że w swojej monografii będzie stosował go częściej niż określenie „islamski”22.

Kierując się powyższymi przesłankami, można powiedzieć, że określenie islamski odnosiłoby się do tego, co związane z samą religią islamu, np. dogmaty „islamu” czy Święta Księga „islamu”. Natomiast przymiotnik „muzułmański” określałby to, co stanowi wytwór (materialny i niematerialny) przedstawicieli tej religii czy też odnosiłby się do wyznawców islamu, czyli np. kultura „muzułmańska” albo obowiązki religijne „muzułmanina”. W celu rozstrzygnięcia, czy bardziej adekwatne jest mówienie o „filozofii muzułmańskiej”, czy o „filozofii islamskiej”, można zastosować rozróżnienie, które przytacza Monika Bobako przy charakteryzowaniu ruchów feministycznych w świecie islamu. Przywołując koncepcję Margot Badarn, Bobako, zauważa, że czym innym jest feminizm „muzułmański”, a czym innym feminizm „islamski”. Przez ten pierwszy rozumie ona

${ }^{20}$ A. Sajid, Islam w relacjach z innymi religiami, tłum. M. Wiertlewska, w: Czerpiąc z korzenia szlachetnej oliwki. Dzień Judaizmu w Poznaniu 2004-2007, red. ks. J. Stranz, Wydawnictwo Naukowe Uniwersytetu im. Adama Mickiewicza w Poznaniu, Poznań 2007, s. 175.

${ }^{21}$ Ibidem, ss. $175-176$.

22 J. Danecki, Podstawowe wiadomości... t. I, s. 11. 
ruchy powstające od końca XIX wieku w państwach muzułmańskich. Miały one przeważnie charakter świecki i opierały się na ideach feministycznych powstałych na Zachodzie. Natomiast feminizm „islamski” rozwinął się pod koniec XX wieku i swoje postulaty formułuje na podstawie zreinterpretowanych islamskich tekstów religijnych ${ }^{23}$. Analogicznie można powiedzieć, że „filozofia muzułmańska”, byłaby to filozofia tworzona przez muzułmanów i osadzona w konkretnym (muzułmańskim) kontekście kulturowym. Natomiast „filozofia islamska” byłaby filozoficznym namysłem, w którym czołowym punktem odniesienia dla prowadzonych analiz byłyby dogmaty islamu, Koran i sunna ${ }^{24}$. W kontekście powyższych rozważań przedstawiony podział nie wydaje się jednak ostry, gdyż, jak zostało wspomniane, muzułmańscy filozofowie podejmowali wiele zagadnień o charakterze religijnym i w swojej argumentacji odwoływali się na przykład do Koranu czy sporów teologicznych ${ }^{25}$. Jednocześnie ci sami uczeni formułowali tezy sprzeczne z islamską ortodoksją. Czy zatem byli bardziej „muzułmańscy”, czy bardziej „islamscy”? Analizując średniowieczne teksty filozofów muzułmańskich, widać, że religia stanowiła ważny element zawartych tam rozważań. Jednak religia, czy ustalenia ortodoksyjnych teologów, nie były kryteriami rozstrzygającymi prawdziwość wniosków, do których dochodzili poszczególni filozofowie. Najlepiej widać to na przykładzie Awerroesa, który będąc religijnym muzułmaninem, nie wzbraniał się przed kategorycznym stwierdzeniem, że to poznanie filozoficzne, a nie teologiczne, ma największą wartość i jest jedyną niezawodną drogą do osiągnięcia prawdy o świecie materialnym i niematerialnym (w tym również o Bogu $)^{26}$. Dlatego też uważam, że to określenie „filozofia muzułmańska” jest najbardziej adekwatne, gdyż z jednej strony uwzględnia aspekt kulturowy oraz

${ }^{23}$ M. Bobako, Islamofobia jako technologia władzy. Studium z antropologii politycznej, Universitas, Kraków 2017, ss. 298-309.

${ }^{24}$ Tak jak przez analogię, dla neotomizmu ramami interpretacyjnymi są dogmaty i nauczanie Kościoła katolickiego.

${ }^{25}$ Wskazuje się, że spory między mu‘tazylitami a aš‘arytami stanowiły inspirację dla awicenniańskiej koncepcji relacji między istotą a istnieniem. Zob. C. Belo, Essence and existence in Avicenna and Averroes. Esencia y existencia en Avicena y Averroes, „Al-Qanțara” 2009, nr 2(30), ss. 403-426, http://al-qantara.revistas.csic.es/index.php/al-qantara/article/view/84/77 [dostęp: 25.06.2010]; R. Wisnovsky, Avicenna's metaphysics in context, Cornell University Press, Ithaca, New York, 2003, ss. 145-181.

${ }^{26}$ Salman Rushdie w swoje powieści Dwa lata, osiem miesięcy i dwadzieścia osiem nocy stawia tezę, że logiczną konsekwencją koncepcji Awerroesa jest ateizm, sam Awerroes miał mieć tego świadomość, ale przestraszył się tej konkluzji, do której miały prowadzić go jego wywody. Dlatego też zdaniem Rushdiego Awerroes nie doprowadził do końca swojego systemu. O domniemanym ateizmie innego wybitnego filozofia muzułmańskiego, Awicenny, pisze Leszek Kołakowski w artykule Awicenna jako filozof. Polski uczony przedstawia tego perskiego filozofa jako myśliciela materialistycznego i empiryka, będącego w ostrym sporze z teologami i odrzucającego myślenie religijne. Zob. S. Rushdie, Dwa lata, osiem miesięcy i dwadzieścia osiem nocy, tłum. J. Kozłowski, Rebis, Poznań 2015; L. Kołakowski, Awicenna jako filozof, w: Awicenna (Abu Ali Ibn Sina), red. A. Zajączkowski, Państwowe Wydawnictwo Naukowe, Warszawa 1953. 
wpływ religii na rozwój tego nurtu intelektualnego, czego brak w pojęciu „filozofia arabska”, z z drugiej - pozwala uniknąć redukcji tej bogatej myśli, która powstała w średniowieczu w świecie islamu, do teologii i jurysprudencji, co do pewnego stopnia może implikować określenie „filozofia islamska”.

\section{Podsumowanie}

Powyższe rozważania pokazują, że pytanie, które postawiłem w tytule niniejszego artykułu, nie ma charakteru tylko językowego. Przyjęcie każdego z prezentowanych w artykule rozwiązań pociąga za sobą również konieczność odpowiedzi na dodatkowe pytania. Przede wszystkim: jak postrzegamy filozofię jako taką? Czy uznajemy, że elementy religijne mogą wpływać na dociekania filozoficzne i je inspirować, czy też obie te sfery - religia i filozofia, powinny być od siebie całkowicie odseparowane? Jak pokazali przytoczeni przeze mnie badacze, ale też sami bohaterowie tego artykułu, czyli muzułmańscy filozofowie, religia odegrała istotną rolę w ich systemach. Dlatego też podejście, które neguje możliwość wzajemnej inspiracji i interakcji między filozofią a religią, jest podejściem błędnym.

Również skupienie się tylko na aspekcie etnicznym czy językowym jest przejawem redukcjonizmu, gdyż pomija istotny wpływ religii na kulturę, z której wywodzili się konkretni twórcy, i która wpłynęła na sposób postrzegania rzeczywistości. To właśnie interakcja myśli antycznych Greków z koncepcjami teologicznymi religii abrahamowych zaowocowała wykształceniem pytań filozoficznych, których antyczni sobie nie stawiali, na przykład pytanie o początek świata i związane z nim pytanie o charakter relacji między istotą a istnieniem w bycie konkretnym ${ }^{27}$.

Na koniec postawię hipotezę, która może stanowić pretekst do dalszych dociekań. Zaryzykować można stwierdzenie, że obstawanie przy określeniu „filozofia arabska” może stanowić przejaw obecnego w zachodnich studiach nad światem islamu orientalizmu i europocentryzmu. Widoczne jest w tym podejściu, świadome lub nie, pomniejszanie wpływu islamu na rozwój światowej myśli i nauki, bądź przez negację (jak u Mrozek) lub przez uznanie, że to język był głównym czynnikiem transmisji i rozwoju tej filozofii (jak u Adamsona i Taylora). Obecne są również tendencje do deprecjonowania tej filozofii jako wtórnej i nieoryginalnej, a także do postrzegania samych muzułmanów jako tych, którzy tylko zachowali, a następnie przekazali łacinnikom dzieła antycznych uczonych ${ }^{28}$. To wszystko powoduje, że określenie „filozofia arabska” w mniejszym lub większym stopniu

${ }^{27}$ D. Kokoć, Creatio ex nihilo a filozoficzne wyodrębnienie problematyki istnienia, „Przegląd Religioznawczy” 2014, nr 1, ss. 55-64.

${ }^{28}$ Taki zarzut stawia między innymi Richard Walzer pod adresem Al-Fārābiego. Uważa on, że dzieła tego muzułmańskiego filozofa stanowią wypisy z zaginionego tekstu greckiego. Zob. R. Brague, Europa, droga rzymska, tłum. W. Dłuski, Teologia Polityczna, Warszawa 2012, s. 97. 
może nieść za sobą nie tylko czysto klasyfikacyjne treści (podkreślenie faktu, że tworzona była przez Arabów i/lub w języku arabskim), ale też pewne ujęcie kultury arabsko-muzułmańskiej jako takiej.

\section{Literatura}

Al-Farabi, Państwo doskonałe. Polityka, tłum. J. Bielawski, PWN, Warszawa 1967.

Al-Ḡazālī A.H., Nisza świateł, tłum. J. Wronecka, PWN, Warszawa 1990.

Al-Ghazali A.H., Sprawiedliwa waga. Ratunek przed zabłqdzeniem, tłum. K. Pachniak, Wydawnictwa Uniwersytetu Warszawskiego, Warszawa 2008.

Averroes (Ibn Rushd), Tahafut al-Tahafut (The Incoherence of the Incoherence), tłum. S. van Den Bergh, http://www.newbanner.com/Philosophy/IbnRushd/Tahafut_al-Tahafut_en.pdf [dostęp: 3.11.2014].

Averroës, Decisive Treaties, Epistle Dedicatory, tłum. Ch.E. Butterworth, Brigham Young University Press, Pravo, Utah 2008.

Avicenna, On Theology, tłum. A.J. Aeberry, Kitab al-Islamiyyah, Dubaj (brak daty wydania). Avicenna, The Metaphysics of The Healing, tłum. M.E. Marmura, Brigham Young University Press, Pravo, Utah 2005.

Awicenna i średniowieczna filozofia arabska, red. A. Aduszkiewicz, M. Gogacz, ATK, Warszawa 1982.

Belo C., Essence and existence in Avicenna and Averroes. Esencia y existencia en Avicena y Averroes, „Al-Qanțara” 2009, nr 2(30), http://al-qantara.revistas.csic.es/index.php/ al-qantara/article/view/84/77 [dostęp: 25.06.2010].

Bielawski J., Al-Farabi - drugi nauczyciel. Życie i dzieło, w: Al-Farabi, Państwo doskonałe..., D. Kokoć, Inspiracje helleńskie...

Bielawski J., Islam, Krajowa Agencja Wydawnicza, Warszawa 1980; idem, Wprowadzenie, w: Koran, tłum. J. Bielawski, PIW, Warszawa 2004.

Bobako M., Islamofobia jako technologia władzy. Studium z antropologii politycznej, Universitas, Kraków 2017.

Brague R., Europa, droga rzymska, tłum. W. Dłuski, Teologia Polityczna, Warszawa 2012.

Corbin H., Historia filozofii muzułmańskiej, tłum. K. Pachniak, Wydawnictwo Akademickie Dialog, Warszawa 2005.

Danecki J., Kultura islamu. Słownik, Wydawnictwa Szkolne i Pedagogiczne, Warszawa 1997;

Danecki J., Podstawowe wiadomości o islamie, t. I, Wydawnictwo Akademickie Dialog, Warszawa 2002.

Dziekan M.M., Dzieje kultury arabskiej, Wydawnictwo Naukowe PWN, Warszawa 2008.

Dziekan M.M., Symbolika arabsko-muzułmańska. Mały słownik, Wydawnictwo Księży Werbistów Verbinum, Warszawa 1997.

Eliade M., Historia wierzeń i idei religijnych, t. III, tłum. A. Kuryś, Instytut Wydawniczy Pax, Warszawa 2008.

Historia filozofii arabskiej, red. P. Adamson, R.C. Taylor, tłum. K. Pachniak, A. Wąs SVD, WAM, Kraków 2015.

Ibn 'Arabi, Drogi do Pana Mocy, tłum. J. Szczepański, Dom Wydawniczy Rebis, Poznań 2003. 
Ibn ‘Arabī, Księga o podróży nocnej do najbardziej szlachetnego miejsca, tłum. J. Wronecka, PWN, Warszawa 1990.

Ibn ‘Arabī, Traktat o miłości, tłum. J. Wronecka, Wydawnictwo Naukowe PWN, Warszawa 1995.

Ibn al'Arabi, The Bezels of Wisdom, tłum. R.W.J. Austin, Paulist Press, New Jersey 1980.

Kokoć D., Awerroistyczna doktryna podwójnej prawdy a współczesne dyskusje na temat relacji między naukq a wiarq, „Humaniora. Czasopismo Internetowe” 2015, nr 3, http:// humaniora.amu.edu.pl/sites/default/files/humaniora/Humaniora\%2011/Kokoc_Hum_3_15_s.pdf [dostęp: 1.07.2016].

Kokoć D., Awerroistyczna doktryna podwójnej prawdy jako próba rozdzielania sfer sacrum i profanum na gruncie filozofii przyrody, „Przegląd Religioznawczy” 2012, nr 4.

Kokoć D., Creatio ex nihilo a filozoficzne wyodrębnienie problematyki istnienia, „Przegląd Religioznawczy” 2014, nr 1.

Kokoć D., Elementy racjonalności w mistyce muzułmańskiej, „Racjonalia. Z punktu widzenia humanistyki” 2011, nr 1.

Kokoć D., Esencjalny charakter metafizyki Ibn 'Arabiego, w: Ratio, religio, humanitas. Miscellanea dedykowane Profesorowi Zbigniewowi Drozdowiczowi, red. E. Jeliński, Z. Stachowski, S. Sztajer, Wydawnictwo Naukowe WNS UAM, Poznań 2015.

Kokoć D., Inspiracje helleńskie w filozofii Al-Farabiego, w: Zachód a świat islamu - Zrozumieć Innego, red. I. Kończak, M. Woźniak, Katedra Bliskiego Wschodu i Północnej Afryki UŁ, Łódź 2012, http://kbwipa.uni.lodz.pl/download/zachod_a_swiat_islamu. pdf [dostęp: 21.04.2012];

Kokoć D., Mistyczna teoria miłości według Ibn “Arabiego”, „Przegląd Religioznawczy” 2011, nr 4.

Kokoć D., Od kalāmu do sufizmu - intelektualno-religijna droga Al-Ḡazālego w Ratunku przed zabłądzeniem, w: Sfery refleksji religioznawczej, red. R. Ilnicki, J. Iwanicki, Wydawnictwo Naukowe WNS UAM, Poznań 2012.

Kokoć D., Relacja między religiq a filozofiq w Traktacie rozstrzygającym Awerroesa, w: Nie tylko Śródziemnomorze. Problemy polityczne i społeczne świata islamu, red. M. Woźniak, Katedra Bliskiego Wschodu i Północnej Afryki Uniwersytetu Łódzkiego, Łódź 2012, http://kbwipa.uni.lodz.pl/download/nie_tylko_srodziemnomorze.pdf [dostęp: 30.12.2012].

Kokoć D., Rola intelektu czynnego w poznaniu Boga w metafizyce Al-Fārābiego, „Humaniora. Czasopismo Internetowe” 2013, nr 1, http://humaniora.amu.edu.pl/sites/default/ files/humaniora/6\%20Rola.pdf [dostęp: 22.12.2013].

Kokoć D., Werset światła w mistyczne interpretacji Al-Ghazalego”, „Internetowy Magazyn Filozoficzny Hybris” 2013, nr 20, http://magazynhybris.com/images/teksty/20/ Hybris_20.\%282013\%29.PDF [dostęp: 3.04.2013].

Kokoć D., Wpływ spuścizny filozofii greckiej na kulturę islamu, „Przegląd Religioznawczy” 2010, $\mathrm{nr} 4$.

Kołakowski L., Awicenna jako filozof, w: Awicenna (Abu Ali Ibn Sina), red. A. Zajączkowski, Państwowe Wydawnictwo Naukowe, Warszawa 1953.

Kuksewicz Z., Awerroizm łaciński trzynastego wieku. Nonkonformistyczny obraz świata i człowieka w średniowieczu, PWN, Warszawa 1971.

Leaman O., Krótkie wprowadzenie do filozofii islamu, tłum. M. Lipszyc, Fundacja Aletheia, Warszawa 2004; 
Machut-Mendecka E., Archetypy islamu, Wydawnictwo Psychologii i kultury Eneteia, Warszawa 2006.

Mrozek A., Średniowieczna filozofia arabska, PWN, Warszawa 1967.

Pachniak K., Fasl al-makal Ibn Ruszda, „Studia Antyczne i Mediewistyczne” 2009, nr 7.

Pachniak K., Filozofia polityki muzułmańskiej na podstawie dzieł Abū Hamida al-Ğazālego, Wydawnictwo Akademickie Dialog, Warszawa 2001.

Pachniak K., Nauka i kultura muzułmańska i jej wpływ na średniowiecznq Europę, Collegium Civitas, Wydawnictwo Trio, Warszawa 2010.

Rushdie S., Dwa lata, osiem miesięcy i dwadzieścia osiem nocy, tłum. J. Kozłowski, Rebis, Poznań 2015.

Sajid A., Islam w relacjach z innymi religiami, tłum. M. Wiertlewska, w: Czerpiqc z korzenia szlachetnej oliwki. Dzień Judaizmu w Poznaniu 2004-2007, red. ks. J. Stranz, Wydawnictwo Naukowe Uniwersytetu im. Adama Mickiewicza w Poznaniu, Poznań 2007.

Stefaniuk T., Al-Kindī i poczq̨tki filozofii w świecie islamu, Wydawnictwo Uniwersytetu Marii Curie-Skłodowskiej, Lublin 2013.

Szymański E., Islam pierwotny, w: Zarys dziejów religii, red. J. Keller, Państwowe Wydawnictwo „Iskry”, Warszawa 1988.

Wisnovsky R., Avicenna's metaphysics in context, Cornell University Press, Ithaca, New York, 2003.

Wisnovsky R., Awicenna i jego tradycja, w: Historia filozofii arabskiej, red. P. Adamson, R.C. Taylor. 
